\title{
06-857, a Green Leaf Lettuce Breeding Line with Resistance to Leafminer and Lettuce Mosaic Virus
}

\author{
Beiquan Mou ${ }^{1}$ and Edward J. Ryder \\ U.S. Department of Agriculture, Agricultural Research Service, 1636 East \\ Alisal Street, Salinas, CA 93905
}

Additional index words. Liriomyza langei, insect resistance, disease resistance, Lactuca sativa, germplasm

Worldwide, leafminers (Liriomyza spp.) are major insect pests of many important crops (Parrella, 1987). The predominant leafminer species in the major lettuce production area of central costal California is Liriomyza langei (Scheffer et al., 2001). The leafminer adult is a small black fly with a bright yellow triangular spot on the upper thorax between the wings. Leafminer damage occurs when adult flies puncture leaves to feed on plant sap and when females lay eggs within the leaf tissue, leaving "stings" that appear as holes or bumps on the leaves. Larvae hatch from the white, oval eggs and feed between upper and lower leaf surfaces, creating whitish, winding tunnels, or "mines" (University of California, 1992). Damage caused by adult stings and larval mining reduces photosynthetic capacity, renders lettuce leaves unmarketable, and provides entrances for disease organisms. Chemical treatment of leafminers usually lasts only a short period of time. Adult leafminer control with contact insecticides is especially difficult because treated fields are subject to reinfestation from adjacent untreated crops and weeds (LeStrange et al., 1999). It has been well documented that leafminers can develop a high degree of resistance to a broad range of insecticides (Keil and Parrella, 1990; Mason et al., 1987; Parrella and Trumble, 1989). Therefore, it is essential to develop alternative strategies for leafminer management, including the deployment of resistant varieties.

Lettuce mosaic virus (LMV) causes serious disease problems for lettuce production worldwide. Plants susceptible to LMV exhibit systemic symptoms of vein clearing, mottling, leaf recurving, leaf margin frilling, distortion, stunting, and occasional necrosis. LMV is primarily transmitted by the green peach aphid (Myzus persicae Sulz.), and can

\footnotetext{
Received for publication 28 Dec. 2009. Accepted for publication $10 \mathrm{Feb} .2010$.

This research was supported in part by grants from the California Leafy Greens Research Program.

We would like to thank JoAnn Tanaka, David Milligan, and Sharon Benzen for technical assistance.

${ }^{1}$ To whom reprint requests should be addressed; e-mail beiquan.mou@ars.usda.gov.
}

describe a green leaf lettuce breeding line with combined resistance to leafminers and LMV, which is adapted to the major lettuce production areas of the central coast of California.

\section{Origin}

The breeding line 06-857 was derived from a cross between crisphead cultivar 'Salinas $88^{\prime}$ that has $m o-l^{e}\left(\mathrm{~mol}^{2}\right)$ alleles (Ryder, 1991), and red leaf cultivar 'Lolla Rossa' that showed low leafminer sting density in previous screening experiments (Mou and Liu, 2003, 2004). The progeny plants were selected in the field of the USDA Agricultural Research Station in Salinas, CA, for horticultural traits and lower sting density in summer when leafminers are abundant. Single plant selections were made by using the pedigree method of breeding from $\mathrm{F}_{2}$ to $\mathrm{F}_{6}$ generation, and $06-$ 857 is an $\mathrm{F}_{7}$ breeding line.

\section{Description}

of resistant cultivars (Zerbini and Gilbertson, 1997). Two recessive resistant alleles at a single locus, mo- ${ }^{g}\left(\mathrm{~mol}^{1}\right)$ and $m o-l^{e}$ $\left(m o l^{2}\right)$, are incorporated in resistant cultivars in Europe and in the United States, respectively (Dinant and Lot, 1992; Ryder, 1970).

The most economical means of insect and disease control is through the use of the natural resistance of plants. This is especially true for organic growers who cannot apply synthetic pesticides and must rely on a combination of genetic resistance, organically certified pesticides, and cultural practices to combat insects and diseases. Repeated pesticide applications may promote pest/pathogen to develop resistance against the chemicals, rendering them ineffective. Resistant varieties could reduce chemical usage, which would benefit growers, consumers, and the environment. However, lettuce cultivars with a high level of resistance to leafminers are not currently available. In this article, we
06-857 is similar to cultivar 'Lolla Rossa' ('Lollo Rossa') except that it is larger and has green leaves (Fig. 1). The green color extends close to the core on a partially trimmed head. Leaf margins are incised, indented, and undulated. The leaf surface is crinkled or blistered. The outer leaves are broader than long. The butt is flat, and ribs are flat but become more prominent toward the base. The bases of the outer and interior leaves overlap well. The texture is relatively soft and flexible, and it has a mild and slightly sweet taste. The seed color is black.

Insect and disease resistance. The breeding line, along with commercial leaf lettuce cultivars, were planted in trials at the Spence Farm of the Agricultural Research Service of the USDA, Salinas, CA, on 28 June 2006, 19 June 2007, 10 June 2008, and 9 June 2009. Leaf lettuce cultivars 'Lolla Rossa' and 'Shining Star' were included in the trials as

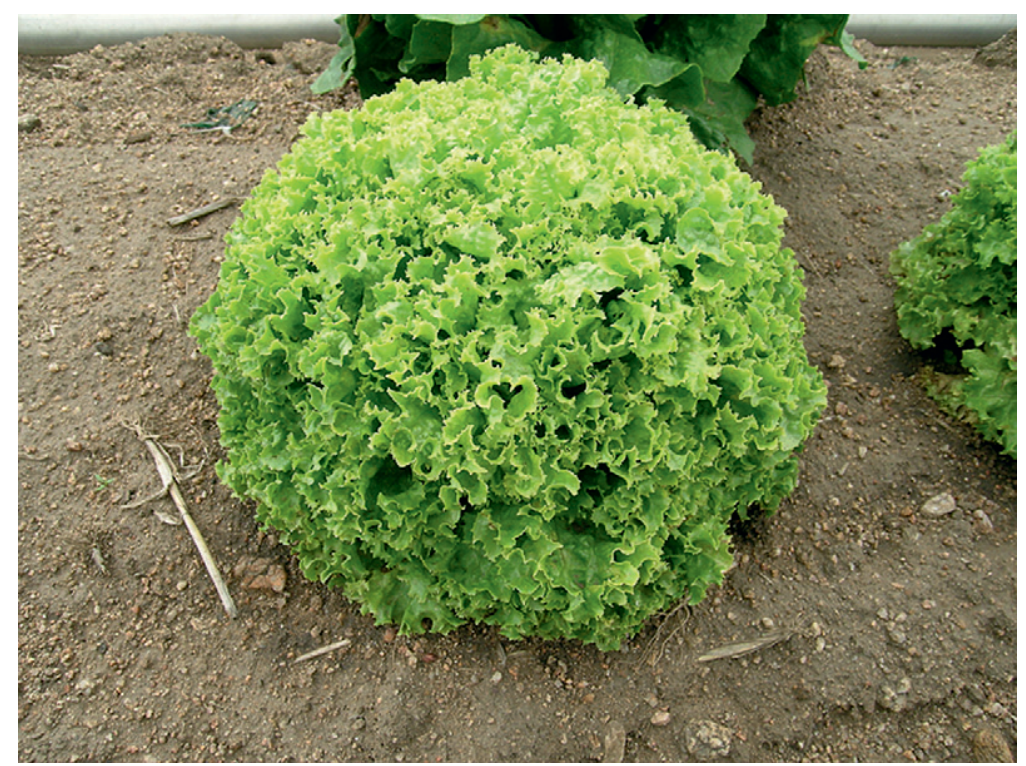

Fig. 1. Lettuce germplasm 06-857 in the field. 
Table 1. Means of leafminer stings per $20 \mathrm{~cm}^{2}$ leaf area, plant weight $(\mathrm{g})$, and core length $(\mathrm{cm})$ for $06-857$ and leaf lettuce cultivars grown in trials from 2006 to 2009 at Spence Farm, Salinas, CA.

\begin{tabular}{|c|c|c|c|c|c|c|c|c|c|c|c|c|}
\hline \multirow[b]{2}{*}{ Genotype } & \multicolumn{3}{|c|}{2006} & \multicolumn{3}{|c|}{2007} & \multicolumn{3}{|c|}{2008} & \multicolumn{3}{|c|}{2009} \\
\hline & $\begin{array}{l}\text { Sting/ } \\
20 \mathrm{~cm}^{2 \mathrm{z}}\end{array}$ & $\begin{array}{l}\text { Plant } \\
\text { wt (g) }\end{array}$ & $\begin{array}{l}\text { Core } \\
(\mathrm{cm})\end{array}$ & $\begin{array}{l}\text { Sting/ } \\
20 \mathrm{~cm}^{2}\end{array}$ & $\begin{array}{c}\text { Plant } \\
\text { wt (g) }\end{array}$ & $\begin{array}{l}\text { Core } \\
\mathrm{cm}\end{array}$ & $\begin{array}{l}\text { Sting/ } \\
20 \mathrm{~cm}^{2}\end{array}$ & $\begin{array}{l}\text { Plant } \\
\text { wt (g) }\end{array}$ & $\begin{array}{l}\text { Core } \\
(\mathrm{cm})\end{array}$ & $\begin{array}{l}\text { Sting/ } \\
20 \mathrm{~cm}^{2}\end{array}$ & $\begin{array}{l}\text { Plant } \\
\text { wt (g) }\end{array}$ & $\begin{array}{l}\text { Core } \\
(\mathrm{cm})\end{array}$ \\
\hline Two Star & $135.8 \mathrm{a}$ & $661.9 \mathrm{a}$ & $5.4 \mathrm{~b}$ & $185.6 \mathrm{a}$ & $559.3 \mathrm{a}$ & $4.5 \mathrm{bc}$ & $162.6 \mathrm{~b}$ & $736.3 \mathrm{ab}$ & $4.8 \mathrm{~d}$ & $143.8 \mathrm{a}$ & $449.4 \mathrm{a}$ & $5.1 \mathrm{bc}$ \\
\hline Waldman's Green & $90.4 \mathrm{~b}$ & $502.6 \mathrm{~b}$ & $8.8 \mathrm{a}$ & $121.0 \mathrm{c}$ & $565.0 \mathrm{a}$ & $8.9 \mathrm{a}$ & $131.5 \mathrm{c}$ & $526.3 \mathrm{c}$ & $9.1 \mathrm{~b}$ & $103.3 \mathrm{~b}$ & $393.7 \mathrm{ab}$ & $9.1 \mathrm{a}$ \\
\hline Shining Star & $75.0 \mathrm{bc}$ & $678.5 \mathrm{a}$ & $11.0 \mathrm{a}$ & $96.1 \mathrm{~d}$ & $477.3 \mathrm{a}$ & $5.2 \mathrm{~b}$ & $109.0 \mathrm{~d}$ & $690.8 \mathrm{~b}$ & $7.6 \mathrm{bc}$ & $96.5 \mathrm{~b}$ & $448.3 \mathrm{a}$ & $7.2 \mathrm{ab}$ \\
\hline Lolla Rossa & $71.9 \mathrm{c}$ & $293.8 \mathrm{c}$ & $9.2 \mathrm{a}$ & $91.8 \mathrm{~d}$ & $160.0 \mathrm{c}$ & $5.2 \mathrm{~b}$ & $96.0 \mathrm{~d}$ & $217.5 \mathrm{~d}$ & $7.2 \mathrm{bcd}$ & $62.0 \mathrm{c}$ & $110.7 \mathrm{c}$ & $2.6 \mathrm{~d}$ \\
\hline Prizehead & - & - & - & - & - & - & $203.9 \mathrm{a}$ & $690.5 \mathrm{~b}$ & $5.9 \mathrm{~cd}$ & $130.5 \mathrm{a}$ & $374.5 \mathrm{ab}$ & $4.3 \mathrm{~cd}$ \\
\hline Big Red & - & - & - & $154.9 \mathrm{~b}$ & $505.8 \mathrm{a}$ & $8.8 \mathrm{a}$ & $170.4 \mathrm{~b}$ & $806.8 \mathrm{a}$ & $13.2 \mathrm{a}$ & $145.9 \mathrm{a}$ & $333.7 \mathrm{~b}$ & $5.0 \mathrm{bc}$ \\
\hline $06-857$ & $43.1 \mathrm{~d}$ & $447.7 \mathrm{~b}$ & $6.6 \mathrm{~b}$ & $52.8 \mathrm{e}$ & $285.3 \mathrm{~b}$ & $3.3 \mathrm{c}$ & $40.9 \mathrm{e}$ & $445.5 \mathrm{c}$ & $5.3 \mathrm{~cd}$ & $32.8 \mathrm{~d}$ & $329.2 \mathrm{~b}$ & $4.3 \mathrm{~cd}$ \\
\hline
\end{tabular}

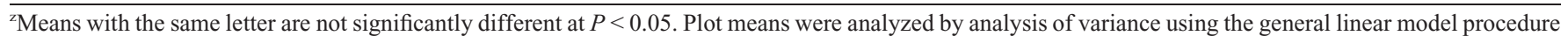
of JMP, version 5 (SAS Institute, Cary, NC). Genotype was considered the fixed effect, and replication was considered the random effect.

resistant controls. The experimental design was a randomized complete block with four replications. Each plot was 14-m long at the commercial spacing of $30 \mathrm{~cm}$ between plants and $35 \mathrm{~cm}$ between rows on a 1-m-wide double-row bed. Standard production practices were followed in each trial. At harvest maturity, three plants were randomly selected in each plot and the number of leafminer stings was counted in a $20 \mathrm{~cm}^{2}$ leaf area with the highest sting density on each selected plant. The breeding line had significantly lower leafminer sting density than resistant controls and commercial cultivars in each of the four trials (Table 1).

06-857 was tested for its resistance to lettuce mosaic following the method described by Ryder (2002). Randomly selected seeds from the breeding line, resistant control 'Salinas 88', and susceptible controls 'Glacier' and 'Misty Day' were sown in plastic pots $(10 \times 10 \times 10-\mathrm{cm})$ containing a mixture of 2 sand: 1 soil (by volume) and were germinated and grown in a greenhouse. Plants were thinned to 16 per pot and were inoculated at the three- to four-leaf stage. The virus used was originally collected from a single plant in a lettuce field in the Salinas Valley in 1958. It has been maintained at the USDA facility in Salinas by plant-to-plant transfer without any apparent loss in virulence. The vector was the green peach aphid, cultured on a long white radish, transferred to LMV-infected lettuce plants, and then to healthy seedlings. Symptoms were evaluated at $22 \mathrm{~d}$ after inoculation. The tests were carried out twice. No plants from $06-857$ or resistant 'Salinas 88 ' exhibited symptoms of lettuce mosaic, while all plants of the susceptible 'Glacier' and 'Misty Day' developed typical disease symptoms (data not shown).

From field observations, 06-857 had moderate resistance to corky root (Sphingomonas suberifaciens) but was susceptible to downy mildew (Bremia lactucae Regel, data not shown). Other disease or insect reactions were not tested.

Performance and adaptation. In the field trials mentioned above, three plants were randomly sampled from each plot. The plants were cut at the ground level and weighed. The heads were then cut open to measure core length and core diameter at the base. The number of leaves with tipburn disorder in each head was also recorded.

In general, 06-857 had a lower plant weight than commercial cultivars, but it was significantly higher than the resistant control 'Lolla Rossa' (Table 1). The core length of the breeding line was similar or shorter than that of the cultivars (Table 1). A relatively short core length is generally preferred by most lettuce processors. 06-857 showed no tipburn in the trials conducted, while varying degrees of tipburn were observed in some commercial cultivars (data not shown).

In the limited trials, the breeding line performed well in the Salinas Valley, producing a high percentage of heads of adequate size, shape, and uniformity. The adaptation of the breeding line to other lettuce-growing regions has not been evaluated.

\section{Seed availability}

Limited samples of seed are available from the corresponding author for distribution to all interested parties for research purposes, including the development and commercialization of new cultivars. Samples will also be deposited in the National Plant Germplasm System. It is requested that appropriate recognition be made if the breeding line contributes to research or the development of new germplasm, breeding lines, or cultivars.

\section{Literature Cited}

Dinant, S. and H. Lot. 1992. Lettuce mosaic virus: A review. Plant Pathol. 41:528-542.
Keil, C.B. and M.P. Parrella. 1990. Characterization of insecticide resistance in two colonies of Liriomyza trifolii (Diptera: Agromyzidae). J. Econ. Entomol. 83:18-26.

LeStrange, M., S. Koike, J. Valencia, and W. Chaney. 1999. Spinach production in California. University of California, Division of Agriculture and Natural Resources, Publication 7212 , p. 3-4.

Mason, G.A., M.W. Johnson, and B.E. Tabashnik. 1987. Susceptibility of Liriomyza sativae and Liriomyza trifolii (Diptera:Agromyzidae) to permethrin and fenvalerate. J. Econ. Entomol. 80:1262-1266.

Mou, B. and Y.B. Liu. 2003. Leafminer resistance in lettuce. HortScience 38:570-572.

Mou, B. and Y.B. Liu. 2004. Host plant resistance to leafminers in lettuce. J. Amer. Soc. Hort. Sci. 129:383-388.

Parrella, M.P. 1987. Biology of Liriomyza. Annu. Rev. Entomol. 32:201-224.

Parrella, M.P. and J.T. Trumble. 1989. Decline of resistance in Liriomyza trifolii (Diptera: Agromyzidae) in the absence of insecticide selection pressure. J. Econ. Entomol. 82:365-368.

Ryder, E.J. 1970. Inheritance of resistance to common lettuce mosaic. J. Amer. Soc. Hort. Sci. 95:378-379.

Ryder, E.J. 1991. 'Salinas 88' lettuce. HortScience $26: 439-440$.

Ryder, E.J. 2002. A mild systemic reaction to lettuce mosaic virus in lettuce: Inheritance and interaction with an allele for resistance. J. Amer. Hort. Sci. 127:814-818.

Scheffer, S.J., A. Wijesekara, D. Visser, and R.H. Hallett. 2001. Polymerase chain reactionrestriction fragment-length polymorphism method to distinguish Liriomyza huidobrensis from L. langei (Diptera: Agromyzidae) applied to three recent leafminer invasions. J. Econ. Entomol. 94:1177-1182.

University of California. 1992. Integrated pest management for cole crops and lettuce. Statewide Integrated Pest Management Project, Div. of Agr. and Natural Resources, Publ. 3307, p. $31-32$.

Zerbini, F.M. and R.L. Gilbertson. 1997. Lettuce mosaic, p. 43-44. In: Davis, R.M., K.V. Subbarao, R.N. Raid, and E.A. Kurtz (eds.). Compendium of lettuce diseases. APS Press, St. Paul, MN. 